\title{
Waterspouts over the North and Baltic Seas: Observations and climatology, prediction and reporting
}

\author{
Nikolai DotzeK ${ }^{1,2 *}$, Stefan Emeis $^{3}$, Christiana LefebVRE ${ }^{4}$ and JÜRgen GerpotT ${ }^{4}$ \\ ${ }^{1}$ Deutsches Zentrum für Luft- und Raumfahrt (DLR), Institut für Physik der Atmosphäre, Oberpfaffenhofen, \\ Germany \\ ${ }^{2}$ European Severe Storms Laboratory (ESSL), Wessling, Germany \\ ${ }^{3}$ Karlsruhe Institut für Technologie (KIT), Institut für Meteorologie und Klimaforschung, Atmosphärische \\ Umweltforschung, Garmisch-Partenkirchen, Germany \\ ${ }^{4}$ Deutscher Wetterdienst, Hamburg, Germany
}

(Manuscript received December 3, 2008; in revised form August 17, 2009; accepted December 9, 2009)

\begin{abstract}
On 25 August 2005, three waterspouts were observed close to the research platform FINO1, $45 \mathrm{~km}$ off the German North Sea coast and situated in a prospected large offshore wind park area. We analyse this case in relation to the synoptic setting of a waterspout day over the Baltic Sea and compare it to the waterspout climatology of the German Bight and the western and south-western parts of the Baltic Sea. The waterspout hazard to offshore wind parks is assessed as about 1 waterspout per year and per $10000 \mathrm{~km}^{2}$. So, should current scenarios for future wind park development materialise, their large total area may experience a waterspout every other year. The prediction of such events is investigated in view of concepts recently proposed for Mediterranean and western North Sea waterspout forecasting. Reporting issues influencing the climatology encompass both a weekend low in reported events, as well as a bias toward ship routes and main SYNOP times in ship reports. The latter may be mitigated by more reports from yachtsmen.

Zusammenfassung

Drei Wasserhosen wurden im August 2005 nahe der Forschungsplattform FINO1 45 km vor der deutschen Nordseeküste beobachtet, in einem für die Errichtung eines großen Windparks vorgesehenen Gebiet. Wir analysieren diesen Fall im Vergleich zur synoptischen Lage eines Wasserhosen-Tags über der Ostsee und ordnen ihn in die Wasserhosen-Klimatologie der Deutschen Bucht und der westlichen und südwestlichen Ostsee ein. Die Bedrohung von offshore-Windparks durch Wasserhosen wird mit etwa 1 Wasserhose pro Jahr und pro $10000 \mathrm{~km}^{2}$ beziffert. Falls heutige Szenarien für den Ausbau solcher Windparks Wirklichkeit werden, kann somit auf deren großer Gesamtfläche alle paar Jahre mit einer Wasserhose gerechnet werden. Die Vorhersage solcher Ereignisse wird im Hinblick auf Konzepte untersucht, die kürzlich für Wasserhosen über dem Mittelmeer und der westlichen Nordsee vorgeschlagen wurden. Probleme bei den Meldungen, die die Klimatologie beeinflussen, sind sowohl ein Wochenend-Minimum der Meldungen, als auch eine Bevorzugung von Schiffsrouten und den synoptischen Hauptterminen bei Schiffswettermeldungen. Solche Einflüsse könnten durch mehr Meldungen von Seglern vermindert werden.
\end{abstract}

\section{Introduction}

Tornadoes are vortices which form from convective clouds and extend to the ground. Waterspouts are tornadoes over extended water surfaces (WEGENER, 1917; cf. DOTZEK, 2003). In general, waterspouts are nonmesocyclonic (and often multi-funnel) tornadoes and hence of lower intensity (cf. GoLDEN, 1999; DOTZEK et al., 2005) than mesocyclonic tornadoes which account for a large portion of the tornadoes over land surfaces in Germany (DOTZEK, 2001, 2005).

Tornadoes and waterspouts can be frightening and threatening phenomena. Therefore, people often have paid attention to them and various descriptions of them in the last centuries have been passed down to our times.

\footnotetext{
${ }^{*}$ Corresponding author: Nikolai Dotzek, Deutsches Zentrum für Luft- und Raumfahrt (DLR), Institut für Physik der Atmosphäre, Oberpfaffenhofen, 82234 Wessling, Germany, e-mail: nikolai.dotzek@dlr.de
}

In the Age of Enlightenment their origin was still unclear. Sulphurous odours were believed to be noticed when they passed; and because they commonly appear together with lightning, their origin from electric forces was discussed (cf. FORSTER, 1778; WILD, 1801; WOLKE, 1802; MuRHARD, 1802 for historic descriptions of and reasoning on waterspouts). Even supposed effects of waterspouts such as fish rain over land were observed and discussed at that time (The fall of herrings at Bernardy, Scotland, took place in June of 1824, probably June 30; and, it was further reported in: "Supposed effects of a water-spout" Philosophical Magazine, August 1824, 152-154.). Only around the turn of the twentieth century, the body of evidence concerning waterspout formation had grown sufficiently to allow for more quantitative conceptual models of waterspouts, as presented, for instance by REYE (1872), FERREL (1893) or WEGENER (1917). 
GOLDEN (1974a, b) and SIMPSON et al. (1986) have further taken into account characteristics of the waterspout life cycle, and demonstrated that it is often initiated by fair-weather cumuli or cumulus congestus ( $\mathrm{Cu}$ con) and not necessarily by thunderstorms. BRADY and SzOKE (1989) as well as WAKIMOTO and WILSON (1989) noted the similar dynamics of waterspouts and non-mesocyclonic tornadoes over land (accordingly sometimes denoted as "landspouts"). Here, pre-existing vertical vorticity within the boundary layer is amplified by vortex stretching below and within the cumulus updraft. Sources for vertical vorticity near the ground may be convergence lines, outflow boundaries from advancing cold pools, or sea breezes. In particular, the collision of two such boundaries moving in opposite directions appears to be a key process to establish vertical vorticity in the boundary layer.

In general, following HouzE (1993) and DoswELL (2001), tornado formation depends largely on the following conditions:

- (potential) instability with dry and cold air masses above a boundary layer capped by a stable layer preventing premature release of the instability;

- a high level of moisture in the boundary layer leading to low cloud bases;

- strong vertical wind shear (in particular for mesocyclonic thunderstorms);

- pre-existing boundary layer vertical vorticity (in particular for non-mesocyclonic convection).

To initiate convection, a source of lift is required, which in the case of waterspouts may be provided by the above mentioned near-surface horizontal convergence.

So although the characteristics of tornado and waterspout formation are understood in principle today, prediction of their actual occurrence remains difficult because the above variety of different favourable conditions have to be met simultaneously. To forecast or nowcast waterspouts, different techniques have been developed, like Doppler radar methods (e.g., CHOY and SPRATT, 1994, 1995) or tailored indices aiming to capture the basic ingredients for waterspout formation (e.g., SZILAGYI, 2009).

From these conditions, one would expect to find waterspouts most frequently over warm oceans. Aside from many historical reports over tropical oceans, this is confirmed by studies from Florida, USA (GOLDEN, 1974a, b, 1999), the Mediterranean (SIOUTAS and KeUL, 2007; KeUL et al., 2009), and Japan (NIINO et al, 1997; SUGAWARA and KOBAYASHI, 2008). But they also occur regularly over waters of moderate temperature, such as the North and Baltic Seas in Europe. In particular, the former is an area in which large offshore wind parks are planned. On 25 August 2005, three waterspouts were observed close to the offshore wind energy research platform FINO1 (NEUMANN et al., 2006) $45 \mathrm{~km}$ off the

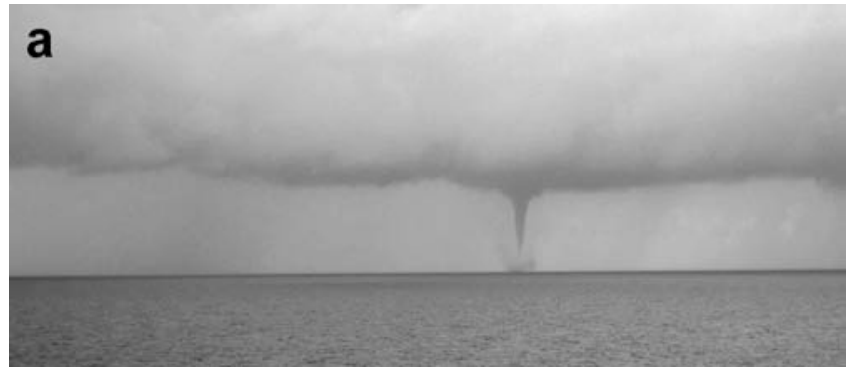

b

Figure 1: Photographs of waterspouts near FINO1 research platform on 25 August 2005: (a) 1135 and (b) 1141 UTC (photos: (a) Christiana Lefebvre, (b) Kim Mittendorf). The image contrast was enhanced by $50 \%$.

coast of the island Borkum in the German Bight between 1100 and 1141 UTC (cf. Fig. 1). Later on, another waterspout occurred more north-eastward, near the German island of Sylt from about 1505 to 1520 UTC. At about 1645, an additional funnel cloud was observed. We use this case to study waterspouts of this area in a more general context, to arrive at conclusions concerning their hazards and prediction.

The paper is organized as follows: Sec. 2 starts with an overview of the German waterspout climatology, while Sec. 3 presents the North Sea case study of 25 August 2005 and compares it to a Baltic Sea waterspout case on 10 April 1951. Despite the limited data availability of this old case, it is useful for comparison, as also a number of waterspouts developed, but from thunderstorms, not fair-weather cumuli. In Sec. 4, waterspout prediction and reporting issues are discussed, and Sec. 5 gives our conclusions.

\section{Climatology}

Significant progress concerning the German severe storms climatology has been achieved by the TorDACH network over a period of 10 years (cf. DOTZEK, 2001, 2003, 2005 and www.tordach.org/de/). Data collection by TorDACH was terminated by the end of 2005, and the data were converted to the European Severe Weather Database format (ESWD, see DOTZEK et al., 2009, and 

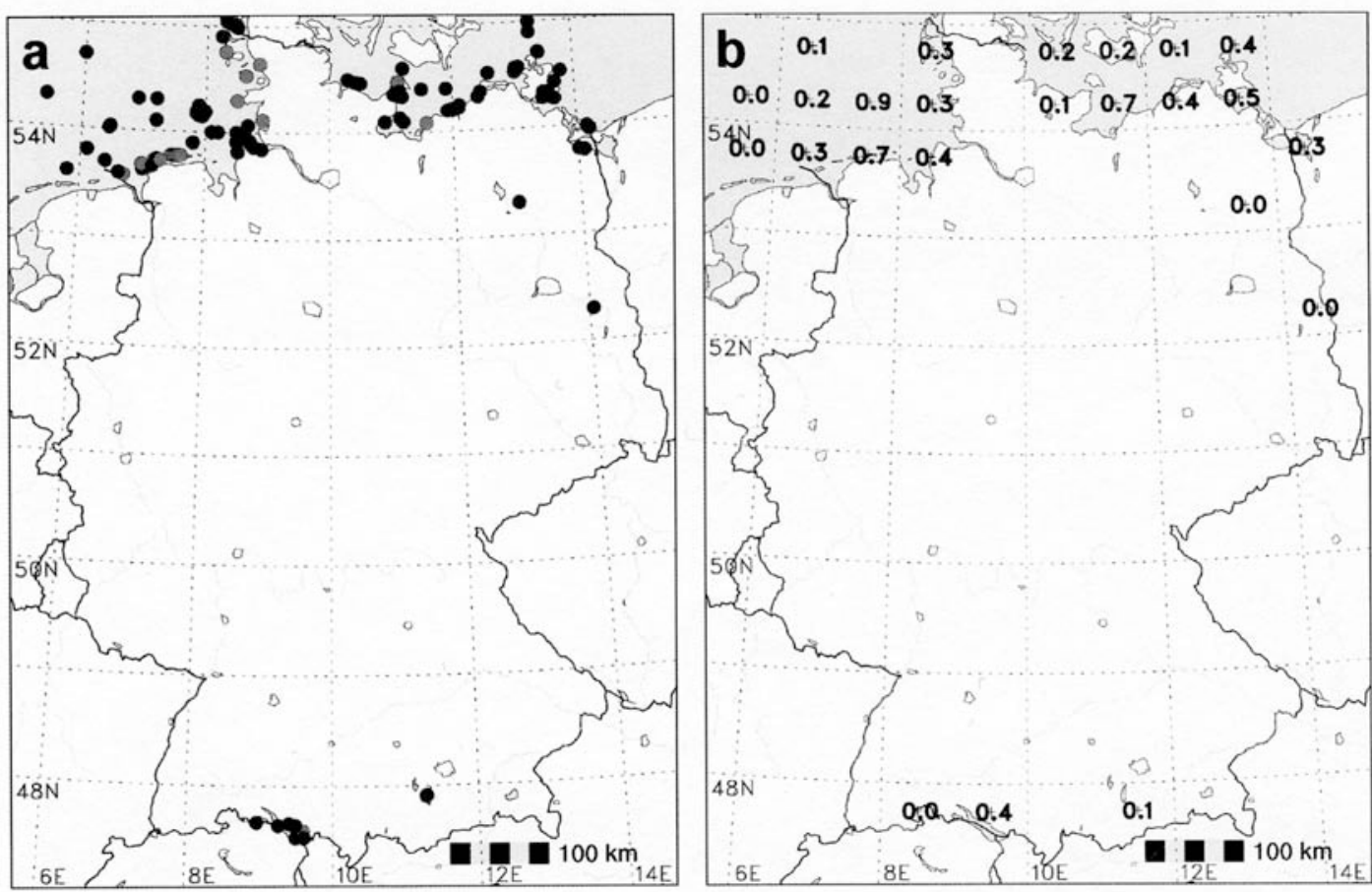

Figure 2: a) TorDACH V1.6 waterspout (dark grey) and landfalling waterspout (medium grey) reports from 1950 to 2005 . b) Incidence from all waterspout reports from 1950 to 2005 in reports per year and per $10000 \mathrm{~km}^{2}$ (rounded to one digit, so 0.0 means 0.0 to 0.05 ; 0.1 means 0.05 to 0.15 reports per year and per $10000 \mathrm{~km}^{2}$ and so forth).

Www.essl.org/ESWD/) and added to it. Since 2006, all German severe storm reports solely contribute to the ESWD.

Here, we outline the German waterspout climatology based on the final, quality-controlled TorDACH dataset V1.6, which will remain unchanged for future comparison of climatological data with the 2005 state of knowledge. Fig. 2a reveals how the locations of waterspouts based on eyewitness reports from 1950-2005 favour the shallow coastal waters of the North and Baltic seas, with a much lower density of reports farther offshore. Lake Constance has another peak of waterspout occurrence.

Unlike the North and Baltic Sea cases, where landsea breezes might contribute to forming convergence lines close to the coast and favourable for waterspout development, the near-surface winds over Lake Constance might be affected by orographic effects of the Alps. Here, mesoscale flow regimes are likely to develop which resemble the land-sea breeze effects present at the seacoast and which might lead to colliding earlymorning land breezes over the lake. This assumption is supported by the fact that except for one report, none of the Lake Constance waterspouts made landfall, but they were apparently coupled to a stationary flow regime over the lake.

Fig. $2 b$ gives the incidence of waterspout reports for the data points in Fig. 2a and substantiates the enhanced density of reports near the coastline, where both land and ship observations contribute to a better complete- ness of reports. The incidence over Lake Constance is quite high and reaches values comparable to those at the seacoast. There, the highest incidence follows for the region around the island of Helgoland (about 0.9 reports per year and per $10000 \mathrm{~km}^{2}$ ). This maximum near Helgoland may be due to two separate reasons: First, the density of observers is obviously much higher on the island than over the nearby waters, and the orography of the island (elevated plain with cliff coast) fosters the observation of waterspouts even farther offshore. Second, orography itself may have an influence on the frequency of waterspout occurrence: The island presents an obstacle to the low-level flow and may help to provide environments prone to waterspout formation by triggering leeward convergence zones in the planetary boundary layer (cf. CHRISTIANSEN and HASAGER, 2005).

For completeness, we note that the numerical values of waterspout incidence over the 56-year period 1950 2005 in Fig. $2 b$ are likely underestimating the true waterspout incidence. This can be seen from Fig. 3a showing the decadal time series of waterspouts in Germany from 1800 to 2005 . Clearly, waterspout reporting has become much more effective since about the year 2000, mainly due to widespread availability of digital camera and video equipment, internet weather forums, and increased awareness among the public. Similar jumps in the number of reported events in the TorDACH archive also occurred for tornadoes over land, damaging winds and hail (not shown), thus paralleling an evolution in re- 

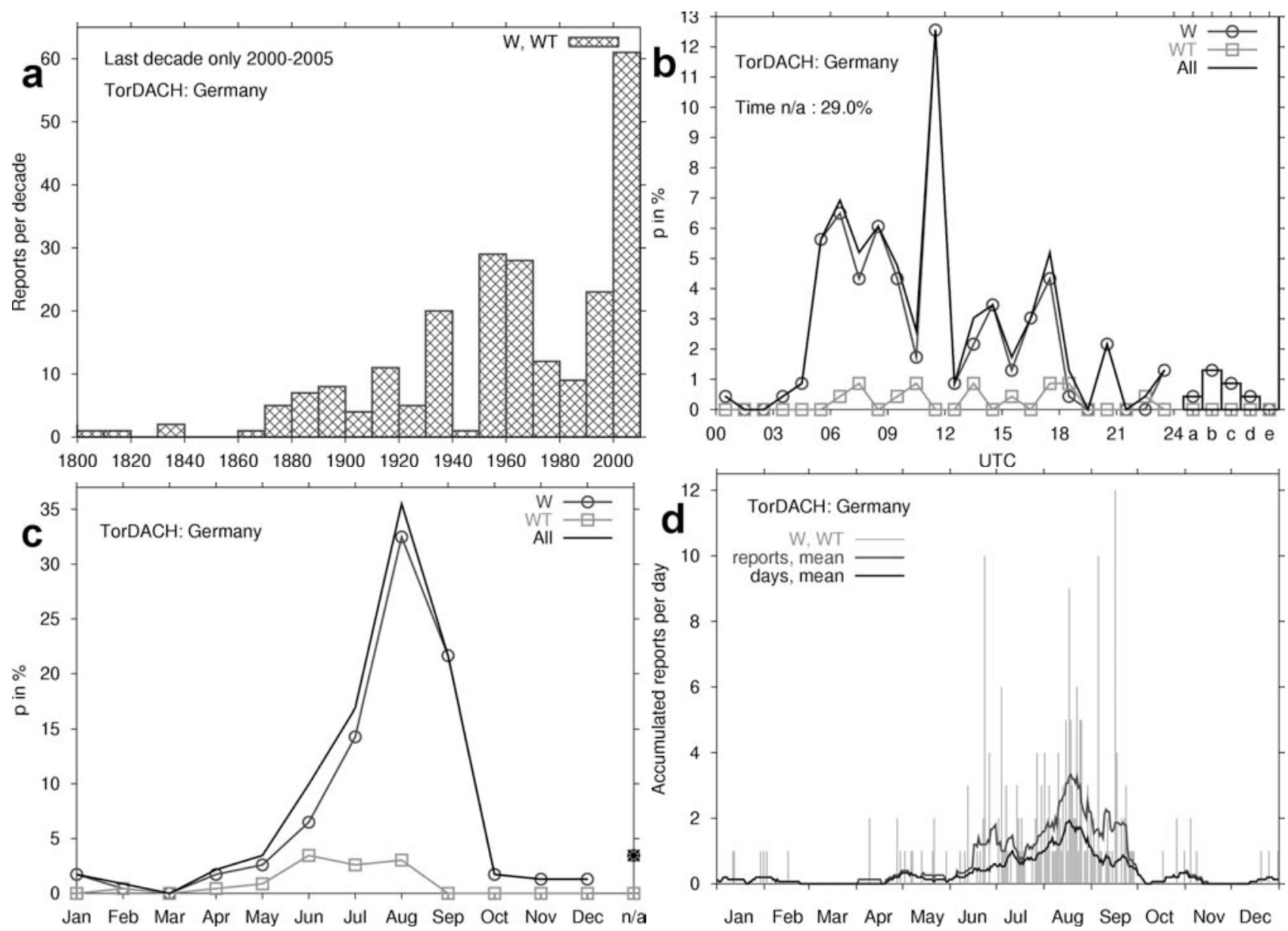

Figure 3: a) Decadal time series, b) diurnal cycle, c) annual cycle monthly, and d) annual cycle, daily, of waterspout (W) or landfalling waterspout (WT) reports in the TorDACH V1.6 database. In b) the bars above labels a-e denote the diurnal cycle for cases in which time was only reported as "morning", "midday", "afternoon", "evening", or "night", respectively.

porting efficiency that took place in the USA after 1953 (cf. DOTZEK et al., 2005, 2009).

Fig. $3 \mathrm{a}$ also shows that jumps in reporting efficiency have occurred earlier as well. Virtually no reports are available before 1880 , which marked the start of the period on which WEGENER (1917) based his climatological analysis of tornadoes in Europe. The strong rise in the 1930s is due to the work of Johannes Letzmann who continued Wegener's research on tornadoes (cf. DotZEK et al., 2008). Again, virtually no reports are available in the 1940s due to World War II, and while the 1950s (from which we show a case in Sec. 3.2) and 1960s saw relatively high numbers of reports, these numbers dropped until the 1980s, due to vanishing interest in the phenomenon. This trend was reversed by the end of the 1990s, when the current rise in reports had its origin.

The diurnal cycle in Fig. $3 b$ exhibits strong variability, likely influenced by a high noise level in the data. Only the supplementary diurnal cycle based on additional cases with coarse time specifications like "morning" or "afternoon" shows a relatively smooth distribution peaking around noon. The climatological expecta- tion for enhanced waterspout occurrence would be the morning or midday hours, when the instability of the marine boundary layer is strongest due to nearly constant sea surface temperatures (SST) and cooling of the air aloft overnight. The noise in Fig. $3 \mathrm{~b}$ with the absolute maximum between 1100 and 1200 UTC is a reporting artefact which can be attributed to the SYNOP ship reports in the TorDACH data. This will be discussed in more detail in Sec. 4.2.

Fortunately, the annual cycle shown in Fig. 3c,d is much better-behaved. Fig. $3 \mathrm{c}$ shows a late-summer to early-autumn maximum in the distribution of "pure" waterspouts, i. e. those which remain offshore during their entire life-cycles. This is plausible for similar reasons as with the expected morning maximum in the diurnal cycle: In August and September, the SST of the shallow coastal waters is still high, while the first autumnal northerly rushes of cold air can lead to an unstable marine boundary layer favourable for waterspout formation in regions where also the boundary layer vertical vorticity is enhanced. This would be the case where horizontal convergence lines occur, possibly in connection with land-sea breezes or outflows from neighbouring convec- 
tion (cf. SiMPSON et al., 1986; BRADY and SzOKE, 1989).

Interestingly, the annual cycle of land-falling waterspouts looks very different, with a broad summer maximum from June to August. This resembles the annual cycle of tornadoes over land which peaks in July (cf. DotZEK, 2001, 2005). Most likely, days with landfalling waterspouts are characterised by environments generally supportive of (severe) thunderstorm formation. Such thunderstorms, in particular mesocyclonic storms forming in a high-shear environment, tend to propagate at a substantial speed and thus enhance the chance of landfall for any tornado forming over water. In this setup, also phenomena like convergence lines over water will be less influential and thus lower the likelihood of a waterspout remaining offshore. For this reason, most of the cases making landfall must be assumed to have been waterspouts from thunderstorms and not from towering cumuli over convergence lines. Fig. 3d shows the accumulated number of waterspout reports per day, revealing again the main late summer peak, but also a secondary peak around the end of June. The 15day boxcar running means of waterspout days ${ }^{1}$ and waterspout reports illustrate that both peak periods of reports are dominated by multi-funnel waterspout events, and that mid-August is the period in which to expect the highest numbers of waterspouts: Both the curves for waterspout days and for the number of reported funnels have their maxima then. In June, however, the weaker maximum does not show up for waterspout days. Thus, the data suggest a high likelihood of multiple funnel waterspout events in this month. Given the limited number of available cases, this secondary maximum may be a sampling artefact, but physical reasons may also play a role. The secondary maximum extends from mid-June to early July. This coincides with the time in which to expect the last notable rush of cold northerly flow before the start of the actual summer season. One may speculate that this airmass would also have higher low-level wind shear and instability.

In this context, Fig. 3d can also be compared to the monthly mean vertical temperature gradient in the troposphere at $50^{\circ} \mathrm{N}, 10^{\circ} \mathrm{E}$ as analysed by EMEIS and KERSCHGENS (1985, their Fig. 2). This gradient has a maximum in the lower troposphere $(850$ to $1000 \mathrm{hPa})$ in June and a tendency towards a second weak maximum in August. In the mid-troposphere (500 to 850 $\mathrm{hPa}$ ), there are two maxima in May and August, while the upper troposphere (200 to $500 \mathrm{hPa}$ ) shows two maxima in May and September. As will be substantiated by the case study in Sec. 3.1, the instability in the lowest $5 \mathrm{~km}$ of the troposphere is relevant for the occurrence of waterspouts. Accordingly, also from this temperature lapse rate analysis we might argue that May-June and August are favourable months for convective events, in-

\footnotetext{
$\overline{{ }^{1} \mathrm{~A} \text { waterspout day is defined as a day on which at least one waterspout was }}$
} reported cluding waterspouts. Due to the much lower SST in June compared to August, it is plausible that the dominant maximum in reported waterspout events in Fig. $3 d$ is in August and only a small secondary peak appears in June. However, only analysis of a larger waterspout sample in the future will allow deciding if the secondary June maximum is a robust feature of the climatology.

Due to the low number of waterspouts with an intensity rating based on the Fujita- or F-scale (cf. FuJITA, 1981), we do not provide a graph with the resulting intensity distribution (which was analysed for tornadoes over land by DotzeK et al., 2003, 2009 and FEUERSTEIN et al., 2005). Instead, we only note here that except for one F3-report, all other cases were confined to F0 to $\mathrm{F} 2$ in intensity (18 to about $\left.60 \mathrm{~m} \mathrm{~s}^{-1}\right)$, that is, only few waterspouts are significant (F2 or higher). This supports the notion that most waterspouts either originate from non-mesocyclonic thunderstorms (cf. DOTZEK et al., 2005), or even non-thundering convection ( $\mathrm{Cu}$ con), so-called "fair-weather waterspouts" (cf. SIOUTAS and KeUl, 2007; KeUL et al., 2007).

Nevertheless, it should be kept in mind that even the lower threshold of the F1-class on the Fujita scale is already at Bft 12 and can thus pose a severe threat to smaller vessels, offshore wind parks, or platforms. One should note here that the wind field in waterspouts is essentially different from the large-scale wind field of an extratropical cyclone. While wind parks or vessels may well withstand winds of $\mathrm{Bft} 12$ or somewhat above, waterspouts pose a higher threat due to their wind shear across the vortex diameter. Large wind energy converters have dimensions similar to those of the waterspout funnels. Thus a wind turbine might experience hurricane-force or stronger winds of opposite directions at the tips of the rotor blades, and the forces thus enacted on the wind turbine are likely to exceed the limits of its design criteria (cf. STORK et al., 1998). For this reason, to build a better knowledge base of the waterspout climatology over the German Bight or the Baltic Sea is also an economically important task due to the big investments required to install many prospected offshore wind energy plants, and further due to the high vessel density (cf. EUROPEAN COMMISSION, 2008).

Assuming an area of about $100 \mathrm{~km}^{2}\left(10 \times 10 \mathrm{~km}^{2}\right)$ as typical for prospective offshore wind parks off the German coast, one can estimate the probability that such a wind park will be affected by waterspouts. We will not compute the probability that a single wind turbine is hit by the vortex centre, i.e. the probability of a mathematical point being hit (Tном, 1963). Due to the horizontal wind shear across the vortex' core and mantle regions, even a near miss by a waterspout may be hazardous for a wind turbine. In addition, it is presently unclear if the small-scale wind field in a wind park altered by the wind turbine wakes themselves (CHRISTIANSEN and HASAGER, 2005) may actually increase the likelihood of a hit once a waterspout enters an array of wind 
turbines. Hence, we focus on the recurrence time of a waterspout anywhere within the wind park instead of at an individual wind turbine site.

Taking the waterspout incidence presently known for the German North Sea coast (about one tornado per $10000 \mathrm{~km}^{2}$ per year, cf. Fig. $2 \mathrm{~b}$ and the estimates by KosCHMIEDER, 1946 or DOTZEK, 2003), one can expect one tornado in an offshore wind park once within one hundred years. This includes the assumption that waterspouts occur homogeneously over the German Bight area. If using the upper limit of Koschmieder's estimate, 2 waterspouts per $10000 \mathrm{~km}^{2}$ per year, the recurrence time is reduced to 50 years for a single wind $\operatorname{park}^{2}$.

While this still seems to be a long interval, one has to take into account that the total area of off-shore wind parks in the German Bight - including both operational facilities and officially approved projects - is $648 \mathrm{~km}^{2}$ (Source: German Federal Maritime and Hydrographic Agency; Bundesamt für Seeschifffahrt und Hydrographie), leading to a recurrence interval of less than eight years for any wind park to be hit by waterspouts in a given year, based on Koschmieder's incidence estimate of 2 waterspouts per year per $10000 \mathrm{~km}^{2}$. A recent report by the European Wind Energy Association (EWEA, 2007) identified that offshore North Sea wind parks with an area of $17900 \mathrm{~km}^{2}$ were needed to supply $180 \mathrm{GW}$, i.e. about $25 \%$ of Europe's current electricity needs. A scenario for 2020 foresees to install enough wind turbines to produce $40 \mathrm{GW}$, which would require about $3980 \mathrm{~km}^{2}$ of wind parks. Should this scenario materialise, one or more waterspouts within an offshore wind park would have to be expected every other year.

\section{Case studies}

\subsection{August 2005, North Sea: FINO1 platform and island of Sylt}

Since September 2003, the research platform FINO1 is operated in the German Bight $45 \mathrm{~km}$ off the coast northwest of the German island Borkum. The platform is located at $54.0239^{\circ} \mathrm{N}, 06.5906^{\circ} \mathrm{E}$, carries a $100 \mathrm{~m}$ tall meteorological mast and has been erected to gain reliable oceanographic and meteorological data for the planning and designing of the first German offshore wind park (cf. NeUmAnN et al., 2006). During a regular service operation, several waterspouts were observed and photographed serendipitously on 25 August

\footnotetext{
${ }^{2}$ This estimate is corroborated by an analysis of waterspout reports in the European Severe Weather Database, ESWD, performed within the research project RegioExAKT. For the climatological time period of 1950-2008, an incidence of about 1.5 waterspouts per year per $10000 \mathrm{~km}^{2}$ results, while for the last decade with highest reporting efficiency, the values are rather 2-3 waterspouts per year per $10000 \mathrm{~km}^{2}$.
}

2005. The observation of the waterspouts a few kilometres away from the instrumented platform FINO1 offers the unique occasion to perform a detailed analysis of the local meteorological situation in which these waterspouts formed in addition to a synoptic assessment of the large-scale weather situation. Fig. 4 displays the synoptic conditions on 25 August 2005 at 1200 UTC from a 12-hour GFS model forecast. The German Bight lay ahead of an upper-level trough which approached from the West. The trough contained rather cold air (about $-25^{\circ} \mathrm{C}$ at $500 \mathrm{hPa}$ ) and exhibited strong horizontal temperature gradients. In contrast to the upper-level conditions, the surface pressure and surface temperature gradients were rather small. The predicted overall vertical instability for the troposphere was weak, as indicated by the Lifted Index (LI). The forecast LI of about 4 at 1200 UTC is usually not sufficient for strong convection and thunderstorms. The Emden radiosonde ascent (WMO station 10200, 53.38 $\mathrm{N}, 07.23^{\circ}$ E, Fig. 5), on the other hand, showed weak instability, confined within the lowest three kilometres AGL. Above this layer, the atmosphere was stable for a parcel representing the lowest $500 \mathrm{~m}$ AGL.

Yet, most of the three favourable conditions mentioned in Sec. 1 for the formation of tornadoes can be identified from this ascent. Aside from the marginal CAPE, there was considerable wind shear $(21 \mathrm{kts}$ at $1350 \mathrm{~m}$ ASL, $39 \mathrm{kts}$ at $2250 \mathrm{~m}, 52 \mathrm{kts}$ at $2750 \mathrm{~m}$, and 64 kts at about $4500 \mathrm{~m}$ ) with a slight veering below 850 $\mathrm{hPa}$. The lifted condensation level (LCL) at $956 \mathrm{hPa}$ (about $400 \mathrm{~m}$ ASL) reflected the high boundary layer moisture and provided a measure of the cloud bases in Fig. 1. Taking this cloud base height as a scale, the geometric dimensions of the waterspouts may be inferred from the photographs by expressing lengths as percentages of the LCL height. Thus, the maximum diameter of the visible funnel is estimated to about 50 to $100 \mathrm{~m}$, and sea spray swirled up from the sea surface up to about 200 to $250 \mathrm{~m}$ ASL (cf. LETZMANN, 1923).

The waterspouts fortunately did not hit the research platform FINO1. The recordings from the platform (Fig. 6) merely showed the features of a gust front passing the platform. Fig. 6a displays an increasing wind speed at about 1035 UTC associated with a beginning decline of the relative humidity. At 1104 UTC, the peak gust occurred, two minutes after a sharp minimum in relative humidity. From about 1125 UTC on, the surface pressure was increasing again. Fig. $6 \mathrm{~b}$ focuses on the time period from 1055 to 1155 UTC. At 1104 UTC, the maximum of the 1 min-mean wind speed was recorded at $90 \mathrm{~m}$ height and at $1106 \mathrm{UTC}$ at $30 \mathrm{~m}$ height. In both cases, the peak speed was around $15 \mathrm{~m} \mathrm{~s}^{-1}$. The peak gusts were just 3 to $5 \%$ higher than the 1-min averages. From 1104 UTC onward, air temperature decreased by about $2 \mathrm{~K}$ until 1130 UTC. Even before the passage of the convective line, the air was already about $1 \mathrm{~K}$ colder than the sea surface. At about 1114 UTC, 

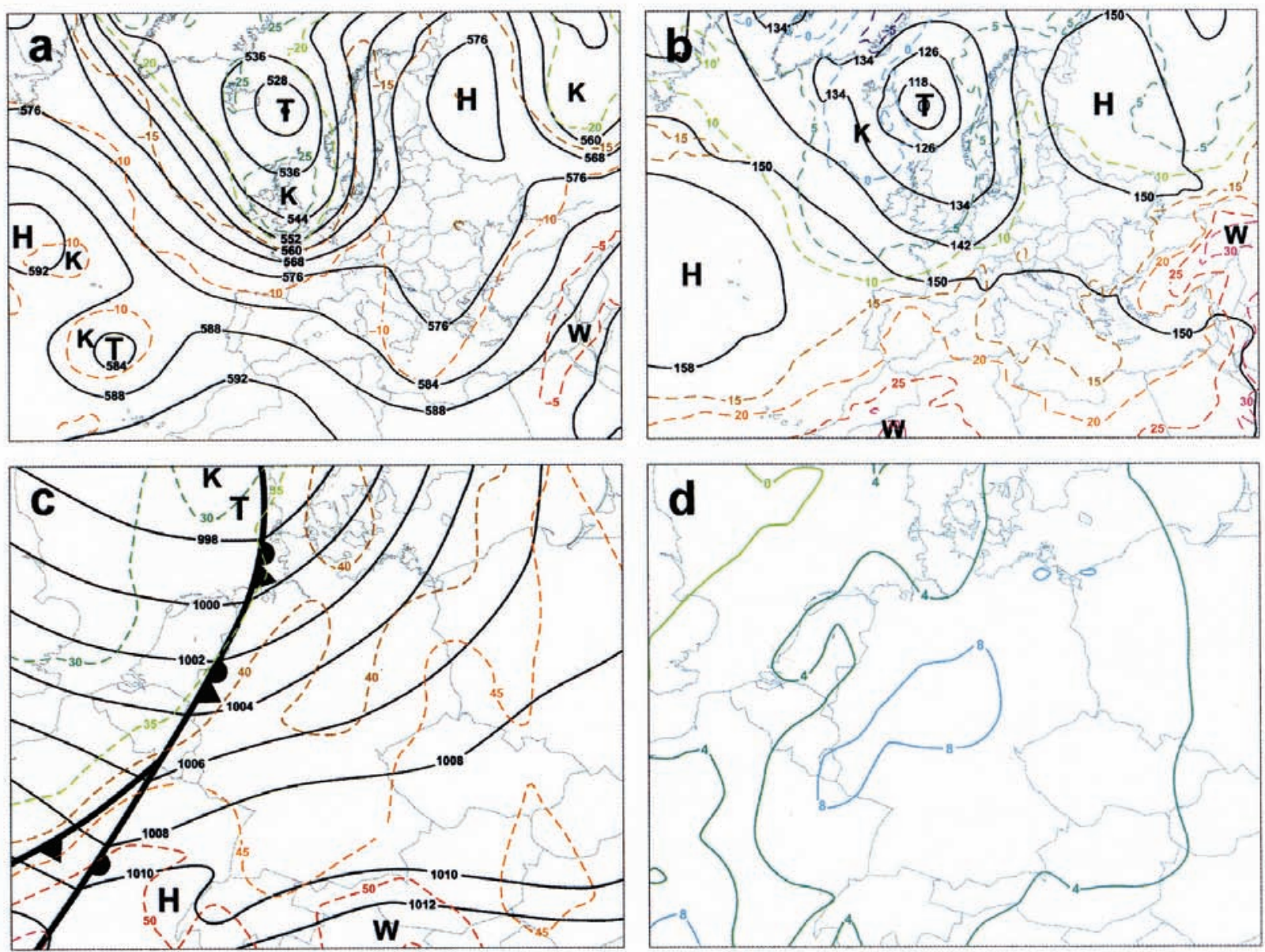

Figure 4: 12-hour GFS model forecasts for 25 August 2005: (a) $500 \mathrm{hPa}$ level (black: geopotential in gpdam, coloured: temperature in ${ }^{\circ} \mathrm{C}$ ), (b) $850 \mathrm{hPa}$ level (black: geopotential in gpdam, coloured: temperature in ${ }^{\circ} \mathrm{C}$ ), (c) surface chart (black: pressure in hPa) with overlay of 850 $\mathrm{hPa}$ equivalent potential temperature in ${ }^{\circ} \mathrm{C}$ (coloured lines), (d) Lifted Index.

Table 1: Selected ship observations made in the Baltic Sea on 10 April 1951. Abbreviations denote: HH = hour of observation (UTC); lat, lon = latitude and longitude in $0.1^{\circ} ; \mathrm{dd}=$ wind direction rounded to next $10^{\circ} ; \mathrm{fff}=$ wind speed in $\mathrm{kts} ; \mathrm{VV}=\mathrm{visibility}(95=2 \mathrm{~km}, 97=10$ $\mathrm{km})$; ww $=$ recent weather $(19=$ tornado $) ; \mathrm{tl}=$ air temperature in ${ }^{\circ} \mathrm{C} ; \mathrm{rf}=$ relative humidity in $\%$; tw $=$ sea surface temperature $(\mathrm{SST})$ in ${ }^{\circ} \mathrm{C}$; dif $=$ difference between air temperature and SST in ${ }^{\circ} \mathrm{C}$.

\begin{tabular}{crrrrrrrrrrrrr}
\hline Date & HH & lat & lon & dd & fff & VV & ww & tl & tf & td & rf & tw & dif \\
\hline 10 Apr 1951 & 0 & 549 & 191 & 16 & 9 & 97 & 19 & 3.0 & & & & & \\
10 Apr 1951 & 0 & 549 & 190 & 18 & 10 & 97 & 19 & & & & & & \\
10 Apr 1951 & 0 & 553 & 156 & 16 & 3 & 97 & 19 & 3.8 & 3.3 & 2.7 & 92 & 7.0 & -3.2 \\
10 Apr 1951 & 0 & 549 & 133 & 9 & 21 & 97 & 19 & 5.2 & & & & & \\
10 Apr 1951 & 12 & 588 & 180 & 11 & 12 & 95 & 19 & & & & & & \\
\hline
\end{tabular}

the mean wind speed reached a second maximum and then started to wane. The temperature decrease during the passage of the gust front was not connected to a significant rise in surface pressure. Therefore it has to be assumed that the cooling was due to cold air advection and not due to strong downdrafts together with heavy precipitation (cf. SUCKSTORFF, 1938; NOTH, 1948). This is reflected also by the wind index WINDEX (MCCANN,
1994) estimating the potential convective wind gusts at the ground from the thermodynamic stratification of the lower troposphere. WINDEX attained values below 10 $\mathrm{m} \mathrm{s}^{-1}$ based on the 1200 UTC Emden proximity sounding. However, formulations of the GUSTEX parameter - which extend WINDEX by including also downward transport of mid-tropospheric horizontal momentum (GEERTS, 2001; DOTZEK and FRIEDRICH, 2009) 


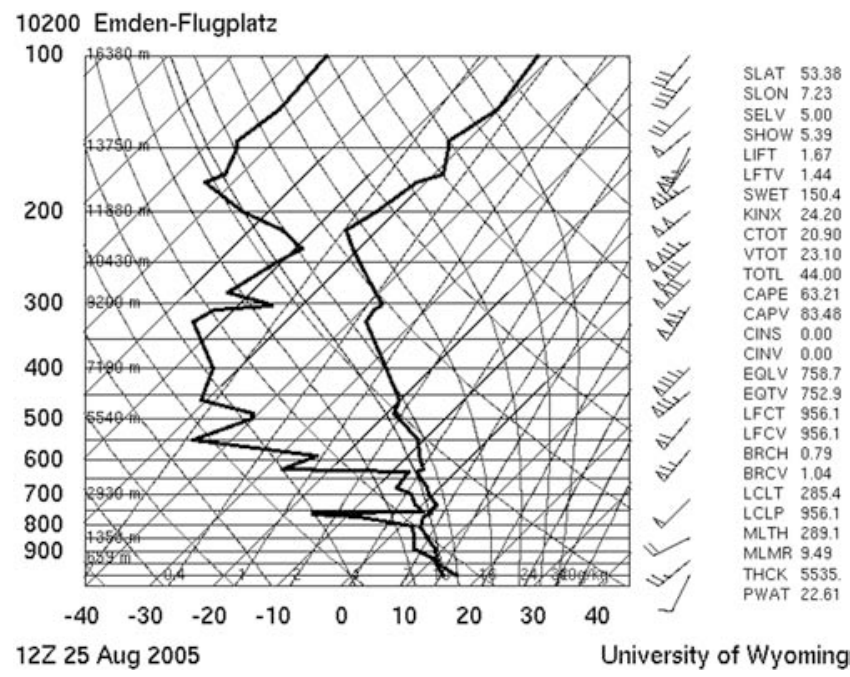

Figure 5: 1200 UTC radiosonde ascent at Emden (north-western Germany at the North Sea coast) on 25 August 2005. The right bold curve gives the dry-bulb temperature in ${ }^{\circ} \mathrm{C}$, the left bold curve the dewpoint in ${ }^{\circ} \mathrm{C}$. With the wind barbs, a short dash denotes $5 \mathrm{kts}$ $\left(2.5 \mathrm{~m} \mathrm{~s}^{-1}\right)$, a long dash $10 \mathrm{kts}\left(5 \mathrm{~m} \mathrm{~s}^{-1}\right)$, a triangle $50 \mathrm{kts}(25$ $\left.\mathrm{m} \mathrm{s}^{-1}\right)$. The ascent of an air parcel representing the lowest 500 $\mathrm{m}$ above ground level (AGL) is shown by a thin curve. (Source: weather.uwyo.edu/-upperair/europe.html).

- computed from the Emden radiosonde ascents at 1200 and 1800 UTC did indicate a moderate potential for convective downdrafts, with potential surface gusts on the order of 18 to $32 \mathrm{~m} \mathrm{~s}^{-1}$.

Precipitation was observed at FINO1 between 1100 and 1104 UTC as well as from 1118 UTC onwards. This is most likely responsible for the increase in relative humidity after the passage of the gust front. From this data, the passage of the surface convergence line (or gust front) itself at which the waterspouts formed, is derived to have happened sometime between 1104 and 1125 UTC.

The convergence line moved eastward and passed the island of Sylt at about 1500 UTC, where another waterspout was observed at that time. Similarly detailed meteorological information as from the FINO1 platform is not available for Sylt. Besides, the closest radiosonde station, Schleswig, had ascents only at 1200 UTC and then 0000 UTC on the next day.

\subsection{April 1951: Waterspouts over the Baltic Sea}

The evaluation of waterspout observations from voluntary observing ships in the marine-meteorological archive of Deutscher Wetterdienst DWD resulted in an accumulation of occurrences on 10 April 1951 over the Baltic Sea (see Table 1). At 0000 UTC (local time LST was UTC plus one hour), four waterspouts over the southern and south-eastern part of the Baltic Sea were observed, out of which two messages off the Gdansk Bay may mean the same event. At noon, another tornado occurred further north in the area of the Swedish islands east of Nynäshamn.

This case is examined having in mind that in the early 1950s, numerical weather analyses and forecasts offering complete information about the atmospheric conditions did not yet exist. The analysis is therefore based on the manually written and analysed weather charts of the former Meteorological Service of North-Western Germany 'Meteorologisches Amt für Nordwestdeutschland, Hamburg' and the publications of the daily weather report 'Täglicher Wetterbericht des Deutschen Wetterdienstes in der US-Zone' (DWD, 1951) and 'Deutsches Meteorologisches Jahrbuch 1951' (MHD-DDR, 1952), containing the data of the radiosonde ascents in the German Democratic Republic.

Fig. 7 displays the synoptic conditions across Europe and the North Atlantic on 10 April 1951, 0000 UTC. Between a high-pressure area across the North Atlantic and an even stronger one over north-eastern Europe, an extended low-pressure system stretched across West and Central Europe. The surface low (Fig. 7a) was embedded in a pronounced trough, expanding to the Mediterranean. While strengthening, this low moved from southern England to the German Bight from 9 to 10 April. Its frontal system crossed the river Elbe by midnight. Rain east of the front marked lifting of warm air ahead of the cold front over the Baltic Sea. At that time, several tornadoes were observed across the southern Baltic Sea. In the course of 10 April, the low relocated slowly to the Danish islands in the western Baltic Sea and the by-then occluded front reached the island Öland around noon. Ahead of the occlusion, another waterspout appeared in the area of the Swedish islands, east of Nynäshamn. To verify the conditions for a genesis of waterspouts pointed out in Sec. 1, only the radio soundings of the German station Greifswald (WMO station $10184,54.09^{\circ} \mathrm{N}, 13.39^{\circ} \mathrm{E}$ ) were available, because other WMO radio sounding stations like Schleswig were not yet in service. At Greifswald, radiosondes were launched twice a day, at 0230 and 1430 UTC, unfortunately only after the tornadoes had been observed. The radiosonde ascents of 9 April at 1450 UTC (20 minutes later than usual, Fig. 8) and 10 April at 0230 UTC show that the atmospheric layering was stable. On 10 April at 0230 UTC, the variation of the relative humidity was parallel to that of the air (dry-bulb) temperature, likely indicating that the mechanic sensor was frozen and not working correctly. Therefore, only the radio sounding in the afternoon of 9 April is taken into further consideration (Fig. 8). It shows moist air at a height of about $2 \mathrm{~km}$, below a small temperature inversion in which the humidity declines, and cold, dry air aloft. No vertical wind shear is seen, because the data did not extend upward far enough. Obviously, the cloud amount of 8/10 $\mathrm{Cu}$ con prevented tracking of the balloon with the theodolite higher than $1.4 \mathrm{~km}$ AGL. 

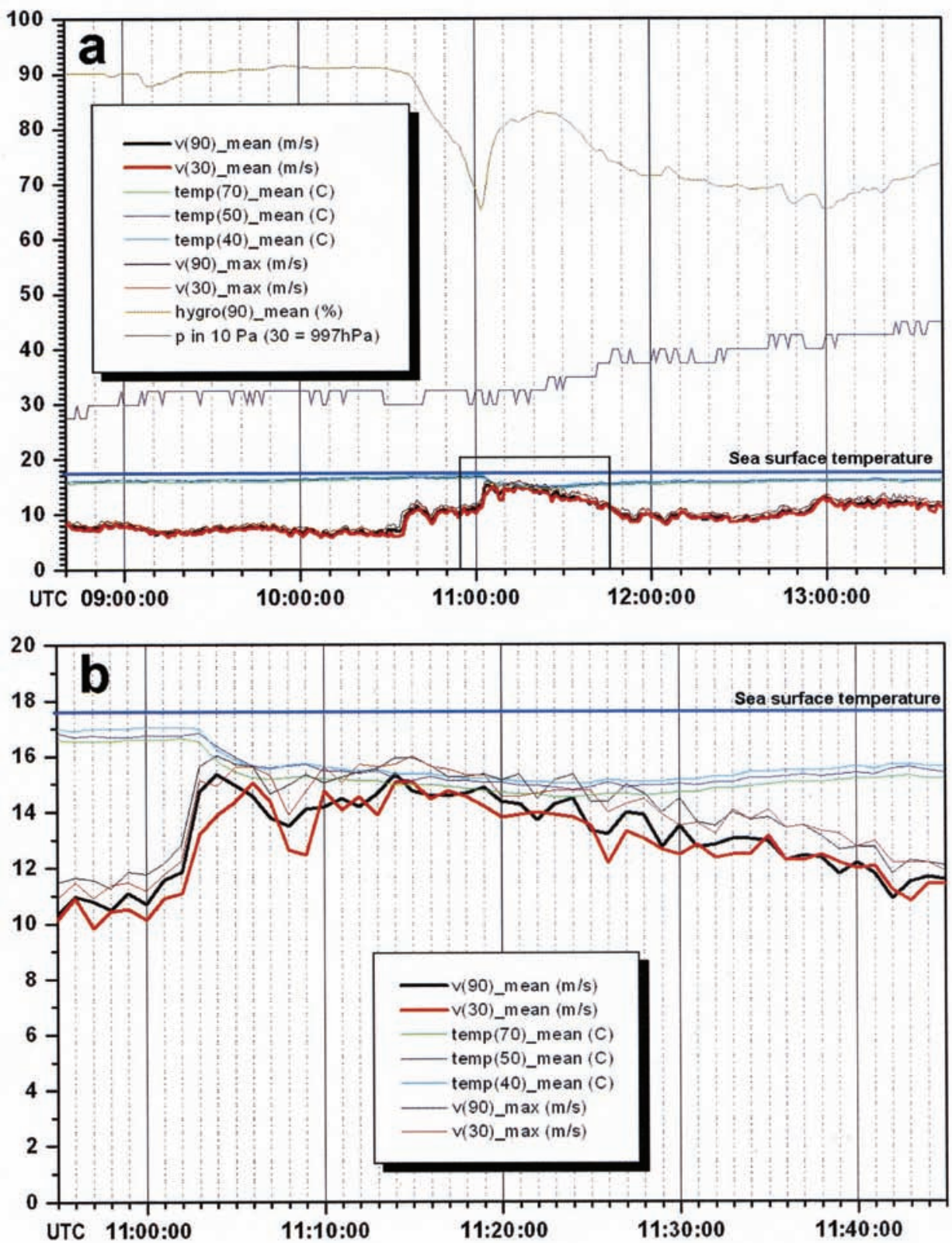

Figure 6: Meteorological recordings at the FINO1 platform on 25 August 2005. a) 0840-1340 UTC. Blue horizontal line: SST in ${ }^{\circ} \mathrm{C}$, bold red and black curve: wind speed in $\mathrm{m} \mathrm{s}^{-1}$ at 30 and $90 \mathrm{~m} \mathrm{ASL}$, thin grey and pink curves: $1 \mathrm{~s}$-gust speeds in $\mathrm{m} \mathrm{s}^{-1}$, light green, violet, and light blue curves (very close together just below SST): air temperature at 70, 50, and $40 \mathrm{~m}$ above sea level, grey-blue: surface pressure in 10 $\mathrm{Pa}(30=997 \mathrm{hPa})$, dark yellow: relative humidity in \%. (b) Close-up of selected meteorological recordings from 1055 to 1145 UTC, marked by the rectangular outline in a).

Assuming that the lower layer of the atmosphere became moister due to the lifting of the air in front of the occlusion and the evaporation of the warmer water of the Baltic Sea (as confirmed by a relative humidity of $92 \%$ in one of the ship observations in Table 1), the radiosonde ascent of 9 April at 1450 UTC may be modified accordingly (Fig. 8). Such modifications are appropriate when the nearest available radiosonde does not represent the boundary layer characteristics at the place of the event in question, cf. HANNESEN et al. (1998).
Accordingly, considering water vapour saturation in the ground layer, the lifted condensation level (LCL) descends to $977 \mathrm{hPa}$, resulting in vertical instability of the troposphere and a convective available potential energy (CAPE) of $935 \mathrm{~J} \mathrm{~kg}^{-1}$.

In addition to the observations of tornadoes, the release of instability in the atmosphere was indicated by the reported occurrence of thunderstorms. In contrast to our North Sea case which was characterised by fairweather waterspouts, the Baltic Sea waterspouts stud- 
ied here had likely originated from thunderstorms, so the significant difference in atmospheric environmental conditions between the two cases is plausible.
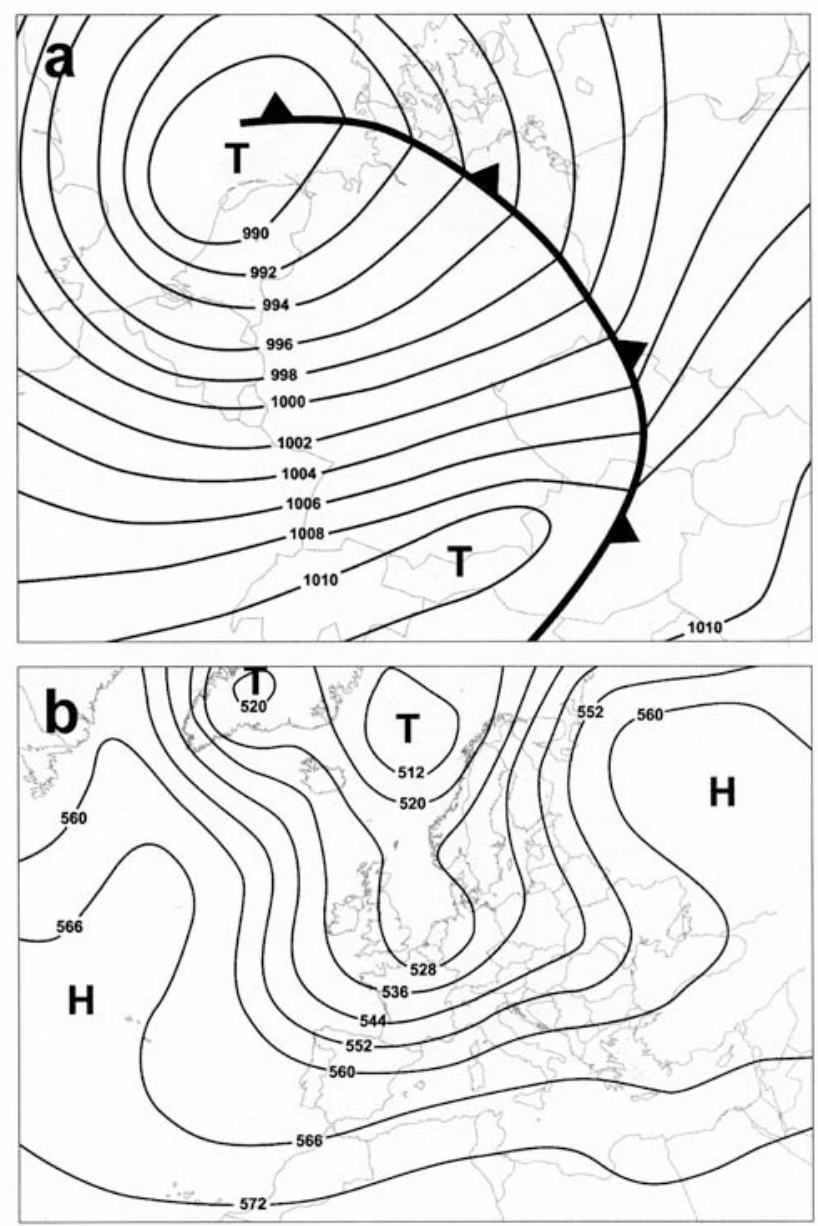

Figure 7: Synoptic situation across Europe and the North Atlantic on 10 April 1951, 0000 UTC; a) Surface air pressure (hPa) and cold front over Central Europe, b) $500 \mathrm{hPa}$ geopotential (gpdam) all over Europe.

\section{Discussion}

\subsection{Waterspout prediction}

BISSOLLI et al. (2007) presented an analysis of the coupling between tornadoes and specific synoptic settings over Germany. However, prediction of actual areas with possible tornado formation requires a forecast of the vertical structure of the lower troposphere with high spatial resolution. The occurrence of the waterspouts on 25 August 2005 was rather unexpected because the predicted instability was low. Partly, the low Lifted Index was caused by the stable stratification of the air mass above $3 \mathrm{~km}$. Therefore, the probability for thunderstorms was small. What must have been decisive for the eventual formation of the waterspouts was the strong vertical wind shear within the lower $3000 \mathrm{~m}$ and strong local instabilities as indicated by the presence of the very shallow layer with dry air ( $25 \%$ relative humidity) at a height of $2250 \mathrm{~m}$ above sea level. The prediction of such shallow layers is probably not feasible with present-day operational weather forecast models.

What can also be concluded from the cases presented here is that commonly used thunderstorm parameters like the Lifted Index can be quite insignificant for the prediction of waterspouts, especially those of the fairweather type. In contrast to the thunderstorm-related waterspouts, there is a clear need to define new, tailored indices to better grasp the cases coupled only to at most towering cumulus ( $\mathrm{Cu}$ con). Such indices should nevertheless rely on quantities which are easy to observe and which are representative for a larger region, not only for the point where the waterspouts occurred.

The latter requirement is illustrated by the fact that even the FINO1 data do not show any extraordinary features which might point to the passage of waterspouts nearby. Only the strong decrease in relative humidity before the passage of the gust front indicates the advection of drier air masses. However, by itself, this feature is not sufficient to expect the occurrence of waterspouts. Thus, the analysis of meteorological surface data alone is not sufficient for either a tornado watch or warning.

However, two recent approaches led to the proposal of waterspout forecast indices for application over the western North Sea (KUIPER and VAN DER HAVEN, 2007) and the central-eastern Mediterranean Sea (KEUL et al., 2007, 2009). The KHS index proposed by KUIPER and VAN DER HAVEN (2007) uses the 0-3 km ASL wind shear, the 0-500 m lapse rate, the average humidity in the lowest $1 \mathrm{~km}$, and the $10-\mathrm{m}$ wind speed as input variables. However, due to its more thorough verification, we apply the method by KEUL et al. (2007, 2009) which uses an empirical nomogram technique (SZILAGYI, 2009) coupling the convective cloud depth, i.e. the distance between the equilibrium level (EL) and the LCL as derived from a sounding, and the temperature difference between the SST and the $850 \mathrm{hPa}$ level as forecast parameters. Under the additional constraint that the $850 \mathrm{hPa}$ winds should be below $40 \mathrm{kts}$, the setting with high waterspout likelihood forms a distinct region in the parameter space, readily usable with the Szilagyi waterspout nomogram shown by KEUL et al. (2007, 2009), see Fig. 9. Note that in the empirical design of the waterspout region boundaries, the goal was not to include all conceivable events, but mainly the most well-defined waterspout cases (SZILAGYI, 2009, pers. comm.).

For the Mediterranean cases, the Keul et al. (2007, 2009) method had a rather high probability of detection (POD) of about $90 \%$. Therefore, it is interesting to apply this method to our cases. On 25 August 2005, when the fair-weather waterspouts were observed, the temperature difference between SST and the $850 \mathrm{hPa}$ level was $17.5^{\circ} \mathrm{C}-5.0^{\circ} \mathrm{C}=12.5 \mathrm{~K}$. Cloud depth based on the Em- 


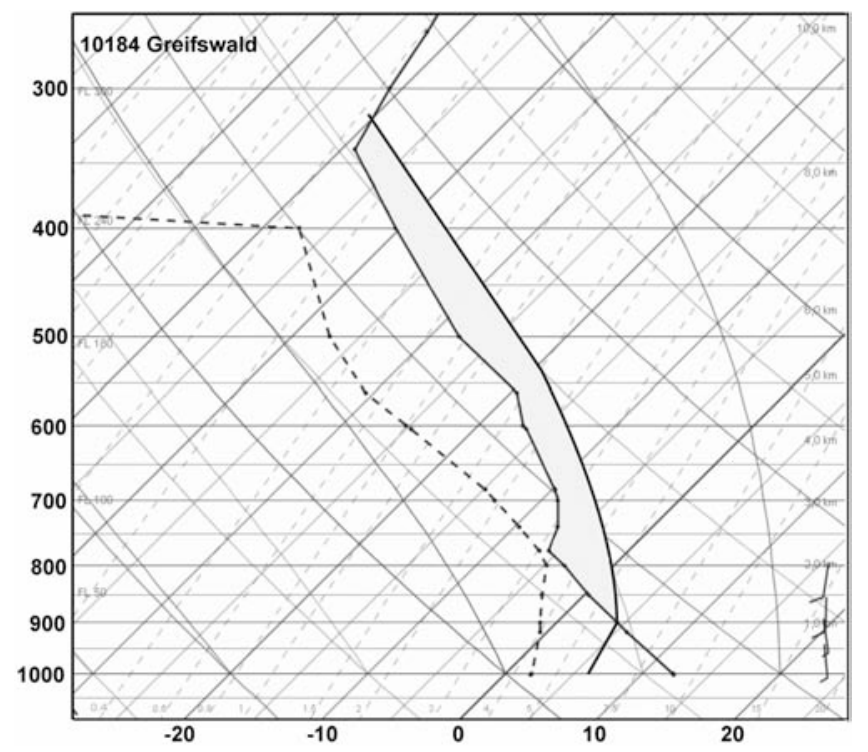

Figure 8: Radiosonde ascent at Greifswald of 9 April 1951 at 1450 UTC. The dashed curve denotes the dewpoint and the middle solid line gives the temperature profile. Wind measurements are only available up to $800 \mathrm{hPa}$. The ascent of an assumed surface parcel with about $12{ }^{\circ} \mathrm{C}$ is given by the rightmost curve and leads to CAPE $=935 \mathrm{~J} \mathrm{~kg}^{-1}$ between about 900 and $320 \mathrm{hPa}$, denoted by the lightgrey area.

den radiosonde (Fig. 5) was about 2000 m. So Fig. 9 shows that this case was outside the waterspout region in the Szilagyi waterspout nomogram of KEUL et al. (2007, 2009) but at least fell beneath their synoptic "upper low" category, in agreement with the observed synoptic situation. Note from Fig. 9 that also KeUL et al. (2009) had consistently shown events from the Aegean and Adriatic Sea in this region of the nomogram. So there appears to be the need to modify the empirical nomogram to include this region of the parameter space as well.

For the 1951 Baltic Sea case, the observed thunderstorm-related waterspouts are corroborated by the lower temperature difference between SST and the $850 \mathrm{hPa}$ level, which was $7.0^{\circ} \mathrm{C}-0.5^{\circ} \mathrm{C}=6.5 \mathrm{~K}$. According to the modified radiosonde ascent, the EL was at 30000 $\mathrm{ft}$. The observed $\mathrm{Cu}$ con cloud base on the afternoon of 9 April was at about $4000 \mathrm{ft}$, such that the resulting convective cloud depth was $26000 \mathrm{ft}$. In the Szilagyi waterspout nomogram of Fig. 9, this is near the lower end of the thunderstorm-related area: A satisfactory result given the limited data available for the 1951 case.

\subsection{Reporting effects on climatology}

Sec. 2 provided an overview of the German waterspout climatology based on the TorDACH data until 2005. The diurnal cycle in Fig. 3b revealed a spiky and noisy signal instead of a smooth distribution and it was argued above that reporting effects in the SYNOP ship reports play a role here. This will now be quantified in more detail, also with respect to the distribution of waterspout reports per weekday.

Most of the spikes in Fig. 3b correspond to the standard meteorological hours, first of all 1200 UTC (note that the points in the graph are plotted at the centre of the hour preceding the reporting time, thus for instance, the 1200 value is plotted at 1130 UTC), then 0600 and 1800 , and secondarily $0900,1500,2100$ and 0000 UTC (plotted at 2330 UTC). The hours between midnight and about 0400 UTC are nearly void of reports, including the 0300 SYNOP reporting time. This quantisation of the reports is predominantly caused by ship reports. So the spikes may indeed be reasonable estimators of the true frequency of waterspouts during their time of day, instead of their appearance as exaggerations. On the contrary, the "valleys" between the spikes give us an impression of how much of the true waterspout occurrence we apparently miss from underreporting.

Apart from the isolated peaks in the diurnal cycle, note the broader period with many reports from about 0500 to 1000 UTC. While this period also contains the 0600 and 0900 spikes, the number of reports remains substantial during the other hours in this period. This may be evidence in support of the climatological expectation of a morning maximum in waterspout occurrence as outlined in Sec. 2. Yet apparently, the noise level still does not lead to a truly smooth distribution during this time of day. A way out of this problem with the coupling of ship reports to the standard SYNOP times is to augment the waterspout database by reports from other vessels which are free to report extreme events immediately. This includes yachtsmen who sail not only the North and Baltic Seas, but also the Mediterranean Sea exactly at the right time of year, during summer and early autumn.

There are also other issues with the reporting of waterspouts which differ significantly from reporting issues known for other severe storm phenomena. The spatial distribution of SYNOP ship reports is also heavily biased towards the main ship routes around Europe, which mainly follow the coastlines or few main routes on open waters (not shown). Again, more public reports from yachtsmen usually avoiding these routes may improve the situation in the future. There is currently an effort taken by the ESSL to augment the ESWD database by establishing contacts to the yachting community and to disseminate the knowledge that waterspout reports can be entered by the ESWD public interface www.essl.org/ESWD/.

Yet, not only do spatial and daytime biases exist in the waterspout reports, but also the reporting frequency by weekday shows some peculiarities which make the climatologist's work more complex, as illustrated in Table 2 for all waterspouts (including events before 1950) as well as the subsets of 1950-2005 only and all Lake Constance cases. We first focus on the data for all waterspouts, a set of 238 reports. Here, the distribution from 


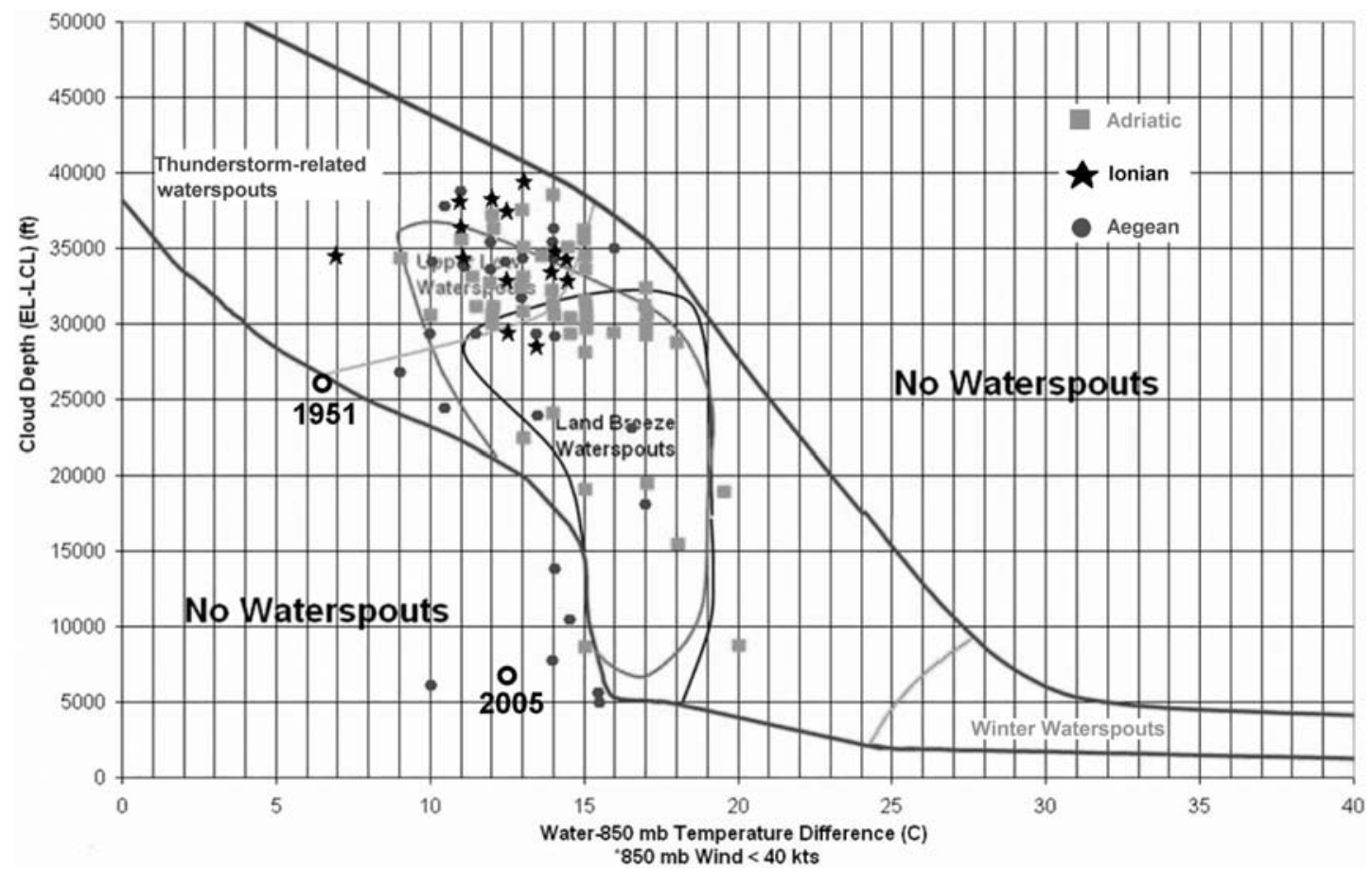

Figure 9: Szilagyi waterspout nomogram after KEUL et al. (2007, 2009) with limiting lines of waterspout occurrence and enclosed areas in parameter space belonging to certain synoptic and mesoscale situations (thunderstorms, upper low, land breeze, winter cold-air outbreak). The two labelled bold open circles indicate the locations of the North and Baltic Sea cases studied here in comparison to the Mediterranean cases from KEUL et al. (2007, 2009).

Table 2: Distribution of waterspout reports by weekday in the region $46^{\circ}$ to $56.5^{\circ}$ latitude, and $5^{\circ}$ to $16^{\circ}$ longitude, split into different reporting categories. For comparison, the subsets of reports since 1950 and of the Lake Constance waterspouts are given. Except for one Thursday event, all Lake Constance waterspouts remained offshore (database: TorDACH V1.6).

\begin{tabular}{|c|c|c|c|c|c|c|c|c|c|c|c|}
\hline & \multicolumn{5}{|c|}{ All reports } & \multicolumn{5}{|c|}{ 1950-2005 reports } & \multirow{2}{*}{$\begin{array}{c}\text { Lake } \\
\text { Constance } \\
\text { All }\end{array}$} \\
\hline & All & $\begin{array}{c}\text { off- } \\
\text { shore }\end{array}$ & $\begin{array}{l}\text { land- } \\
\text { falling }\end{array}$ & $\begin{array}{l}\text { ship } \\
\text { report }\end{array}$ & $\begin{array}{l}\text { ground } \\
\text { report }\end{array}$ & All & $\begin{array}{c}\text { off- } \\
\text { shore }\end{array}$ & $\begin{array}{l}\text { land } \\
\text { falling }\end{array}$ & $\begin{array}{l}\text { ship } \\
\text { report }\end{array}$ & $\begin{array}{l}\text { ground } \\
\text { report }\end{array}$ & \\
\hline$n$ & 238 & 212 & 26 & 50 & 188 & 169 & 148 & 21 & 49 & 120 & 38 \\
\hline Mon & 31 & 29 & 2 & 10 & 21 & 20 & 19 & 1 & 10 & 10 & 12 \\
\hline Tue & 48 & 38 & 10 & 8 & 40 & 39 & 30 & 9 & 8 & 31 & 3 \\
\hline Wed & 30 & 23 & 7 & 7 & 23 & 21 & 15 & 6 & 7 & 14 & 6 \\
\hline Thu & 32 & 30 & 2 & 9 & 23 & 19 & 17 & 2 & 8 & 11 & 6 \\
\hline Fri & 30 & 29 & 1 & 8 & 22 & 27 & 26 & 1 & 8 & 19 & 3 \\
\hline Sat & 26 & 22 & 4 & 4 & 22 & 21 & 19 & 2 & 4 & 17 & 1 \\
\hline Sun & 23 & 23 & 0 & 4 & 19 & 18 & 18 & 0 & 4 & 14 & 1 \\
\hline $\mathrm{n} / \mathrm{a}$ & 18 & 18 & 0 & 0 & 18 & 4 & 4 & 0 & 0 & 4 & 6 \\
\hline
\end{tabular}

Monday to Friday is relatively homogeneous with about 30 reports on each weekday. Only Tuesday makes an exception with 48 reports, but this may be a coincidental effect due to a number of multi-funnel events on this weekday in the relatively small sample of 238 reports.

However, during the weekend, the reporting drops to 26 reports on Saturday and 23 reports on Sunday, that is, by roughly $17 \%$ compared to the rest of the week. One might argue that the lower numbers during the week- end are just as coincidental as the peak on Tuesday, but the likelihoods of upward and downward variability are not equally distributed. It may well be that a few large events push the numbers for one particular weekday upward (i. e., for a minority of realisations of the full sample), but to have low numbers on just one or two days of the week by coincidence would imply that all other days had been favoured by chance (i. e., a majority of the possible realisations). As there are no "negative wa- 
terspouts" in nature, the likelihood of peaks and gaps in a discrete distribution is asymmetric. Hence, there is a higher level of confidence that days with low number of reports are significant than for isolated days with aboveaverage reports.

That said, one can analyse the set of 238 waterspouts and split it up into either offshore and landfalling cases or into ship reports versus ground reports. In all of these, there is a tendency for low numbers during the weekend, most pronounced in the list of ship reports, where the reporting drops by more than $50 \%$ compared to the rest of the week. Similar results hold for the 1950-2005 subset of the data. One might imagine reasons why waterspout reports drop on Saturdays and Sundays: Manned meteorological observing stations may switch to automatic operations during the weekend; a Saturday waterspout may have a smaller chance to be still mentioned in the Monday news, and so on. But all these options refer to reports from ground stations and cannot explain why one should have $50 \%$ less SYNOP waterspout reports from ships on Saturdays and Sundays, unless the vessel densities themselves had a minimum during the weekend.

Interestingly, a similar effect can be seen in the list of the 38 Lake Constance waterspouts in Table 2. Also here, Saturday and Sunday yield by far the lowest numbers of reported events. As these are all ground reports, the abovementioned reasons may have played a role. But it is certainly striking that in all categories of Table 2, the weekend waterspouts have either the lowest numbers or are at least close to the days with the lowest numbers. It would be helpful if the data sample were larger, for instance by routinely including all SYNOP reports to the ESWD database in the future, but for the time being, we have to settle with the available numbers. Furthermore, as waterspouts are not recorded in the United States tornado database, there is also no US climatology available for comparison to our findings.

\section{Conclusions}

Apart from the probably still increasing transport volumes on shipping routes in the North and Baltic Seas, especially the planned establishment of large offshore wind parks will make this region more vulnerable to weather hazards. In view of this fact, our study of reported waterspout events over the German Bight and the Baltic Sea showed:

- For present offshore wind park development scenarios for 2020, waterspout events anywhere within such parks may occur every other year in the future;
- The Lifted Index does not appear to be a suitable predictor for the formation of waterspouts, in particular those of the fair-weather type not related to thunderstorms. A possibly more appropriate predictor should focus on low-level instability and wind shear, as proposed by KEUL et al. (2007, 2009). The predictive skill of such parameters to forecast the occurrence of waterspouts and tornadoes over land has to be further tested from a statistically significant number of cases for each climatologically distinct region;

- The Szilagyi waterspout nomogram concept is a very promising approach to operational waterspout forecasting. However, based on our 2005 case and several of the cases presented by KEUL et al. (2009), a modification of the empirical Szilagyi waterspout nomogram in the parameter region below the "upper low" and "land breeze" waterspouts appears advisable to include a presently uncovered parameter region with consistent occurrence of waterspouts;

- Even detailed local meteorological surface measurements just a few kilometres away from waterspouts may not be sufficient to indicate their occurrence. Therefore, tornado and waterspout statistics will have to rely on visual observations for some time to come, despite potential improvements from new forecast indices;

- The waterspout climatology over the North and Baltic Seas is still significantly affected by reporting issues arising from preferred observation regions (main ship routes) or reporting times (SYNOP main meteorological hours). These may be mitigated by more reports from yachtsmen;

- The observed tendency for low numbers of reported waterspouts during the weekend awaits both reevaluation based on larger sample sizes, and a convincing explanation should it prove to be a robust feature.

With further development of the European Severe Weather Database ESWD, we can expect to obtain the necessary large, consistent set of waterspout reports over all European waters in the near future.

\section{Acknowledgments}

The authors thank Andreas BECK, DWD-Luftfahrtberatungszentrale Nord for his valuable support in adjusting and discussing the radio soundings, and Wade SZILAGYI for valuable comments on his waterspout nomogram. We also gratefully acknowledge the availability of the following internet resources: www.essl.org/ESWD/, www.tordach.org, and weather.uwyo.edu/upperair/ europe.html. Caroline FORSTER provided insightful suggestions to an earlier version of the manuscript, 
and the comments by our two referees helped to improve the paper. This work was partly funded by the German Federal Ministry for the Environment, Nature Conservation and Nuclear Safety (BMU) which supported the analysis of the FINO1-data within the framework of the OWID (Offshore WInd Design parameters) project through grant no. 0329961, and the German Federal Ministry of Education and Research (BMBF) under contract 01LS05125 in the project RegioExAKT (Regional Risk of Convective Extreme Weather Events: User-oriented Concepts for Trend Assessment and Adaptation, www.regioexakt.de) within the research programme klimazwei.

\section{References}

Bissolli, P., J. Grieser, N. DotzeK, M. Welsch, 2007: Tornadoes in Germany 1950-2003 and their relation to particular weather conditions. - Global Planetary Change 57, 124-138.

BRADY, R.H., E.J. SzOKE, 1989: A case study of nonmescocyclone tornado development in Northeast Colorado: Similarities to waterspout formation. - Mon. Wea. Rev. 117, 843-856.

ChOY, B.K., S.M. SpRATT, 1994: A WSR-88D Approach to waterspout forecasting. - NOAA Tech. Memo. NWS SR-156, Ft. Worth, TX, 25 pp., online at www.srh.noaa.gov/mlb/spout.html

—, —, 1995: Using the WSR-88D to predict East Central Florida waterspouts. - Preprints, 14th Conf. on Weather Analysis and Forecasting, Dallas, TX, 376-381, online at www.srh.noaa.gov/mlb/spoutpre.html

Christiansen, M.B., C.B. HASAGER, 2005: Wake effects of large offshore wind farms identified from satellite SAR. Rem. Sens. Environ. 98, 251-268.

Doswell, C.A., (Ed.) 2001: Severe Convective Storms. Meteor. Monogr. 28(50), 561 pp.

DotzeK, N., 2001: Tornadoes in Germany. - Atmos. Res. 56, 233-251.

- 2003: An updated estimate of tornado occurrence in $\mathrm{Eu}-$ rope. - Atmos. Res. 67-68, 153-161.

—, 2005: Tornado- und Downburstklimatologie (Tornado and downburst climatology). - Klimastatusbericht 2004. DWD, Offenbach, 171-180. [In German]

DotzeK, N., K. FRIEDRICH, 2009: Downburst-producing thunderstorms in southern Germany: Radar analysis and predictability. - Atmos. Res. 93, 457-473.

Dotzek, N., J. GRIESER, H.E. BROOKS, 2003: Statistical modeling of tornado intensity distributions. - Atmos. Res. 67-68, 163-187.

Dotzek, N., M.V. Kurgansky, J. Grieser, B. FeuerSTEIN, P. NÉVIR, 2005: Observational evidence for exponential tornado intensity distributions over specific kinetic energy. - Geophys. Res. Lett. 32, L24813, DOI:10.1029/2005GL024583.

Dotzek, N., R.E. Peterson, B. Feuerstein, M. HubriG, 2008: Comments on "A simple model for simulating tornado damage in forests". - J. Appl. Meteor. Climatol. 47, 726-731.

Dotzek, N., P. Groenemeijer, B. Feuerstein, A.M. HOLZER, 2009: Overview of ESSL's severe convective storms research using the European Severe Weather Database ESWD. - Atmos. Res. 93, 575-586.
DWD (Ed.), 1951: Täglicher Wetterbericht (Daily weather report). - Deutscher Wetterdienst in der US-Zone, Zentralamt, Bad Kissingen, Jahrgang 1951.

EmeIs, S., M.J. KerschGens, 1985: Sensitive pressure transducer to deduce the structure of mesohighs. - Beitr. Phys. Atmos. 58, 407-411.

EUROPEAN COMMISSION (Eds.), 2008: An ocean of opportunity: An integrated maritime policy for the European Union. - Directorate-General for Maritime Affairs and Fisheries, 20 pp.

EWEA (Eds.), 2007: Delivering Offshore Wind Power in Europe. - Report, European Wind Energy Association, Brussels, 32 pp., available at www.ewea.org/fileadmin/ewea_documents/images/publications/offshore_report/eweaoffshore_report.pdf

FERrEL, W., 1893: A Popular Treatise on the Winds, 2nd ed. - MacMillan and Co., London, 505 pp.

Feuerstein, B., N. DotzeK, J. Grieser, 2005: Assessing a tornado climatology from global tornado intensity distributions. - J. Climate 18, 585-596.

Forster, J.R., 1778: Observations made during a voyage round the world. - London, printed for G. Robinson. Reprint 1996, University of Hawaii Press, 526 pp.

FuJITA, T.T., 1981: Tornadoes and downbursts in the context of generalized planetary scales. - J. Atmos. Sci. 38, 15111534.

GEERTS, B., 2001: Estimating downburst-related maximum surface wind speeds by means of proximity soundings in New South Wales, Australia. - Wea. Forecast. 16, 261-269.

Golden, J.H., 1974a: The life cycle of Florida Keys' waterspouts. I. - J. Appl. Meteor. 13, 676-692.

—, 1974b: Scale-interaction implications for the waterspout life cycle. II. - J. Appl. Meteor. 13, 693-709.

-, 1999: Tornadoes. - In: Pielke, R. JR., R. PIElke SR. (Eds.), Storms, Vol. II, 103-132. Routledge Hazards and Disasters Ser. 2, Routledge, London and New York, 345 pp.

Hannesen, R., N. DotzeK, H. Gysi, K.D. Beheng, 1998: Case study of a tornado in the Upper Rhine valley. - Meteorol. Z. 7, 163-170.

Houze, R.A., 1993: Cloud Dynamics. - Academic Press, San Diego, 570 pp.

Keul, A.G., M.V. Sioutas, W. SzIlagyi, 2007: Prognosis of Central-Eastern Mediterranean waterspouts. - Preprints, 4th European Conf. on Severe Storms, 2 pp., available from www.essl.org/ECSS/2007/abs/07Climatology/1178114308.keul-1-sec07.oral.pdf

Keul, A.G., M.V. Sioutas, W. SzIlagyi, 2009: Prognosis of Central-Eastern Mediterranean waterspouts. - Atmos. Res. 93, 426-436.

Koschmieder, H., 1946: Über Böen und Tromben (On straight-line winds and tornadoes). - Die Naturwiss. 34, 203-211, 235-238. [In German]

KUIPER, J., M. VAN DER HAVEN, 2007: A new index to calculate risk of waterspout development. - Preprints, 4th European Conf. on Severe Storms, 1 p., available from www.essl.org/ECSS/2007/abs/06Forecasts/1179250265.kuiper.pdf

LETZMANN, J.P., 1923: Das Bewegungsfeld im Fuß einer fortschreitenden Wind- oder Wasserhose (The flow field at the base of an advancing tornado). - Ph.D. Thesis, University of Helsingfors. Acta et Commentationes Universitatis Dorpatensis AVI.3, C. Mattiesen Verlag, Dorpat, 136 pp., in German, available from www.essl.org/pdf/- 
Letzmann1923/Letzmann1923.pdf

MCCANN, D.W., 1994: WINDEX - A new index for forecasting microburst potential. - Wea. Forecast. 9, 532-541.

MHD-DDR (Ed.), 1952: Deutsches Meteorologisches Jahrbuch (German Meteorological Yearbook) 1951, Teil V, Heft 1, 2 und 3. - Meteorologischer und Hydrologischer Dienst der Deutschen Demokratischen Republik, Deutscher Zentralverlag, Berlin, 1, 24; 2, 5; 3, 14-17.

MURHARD, F., 1802: Beschreibung mehrerer auf dem mittelländischen Meere beobachteten Wasserhosen (Description of several waterspouts observed over the Mediteranean Sea). - Ann. Phys. 12, 239-245.

Neumann, T., S. Emeis, C. ILLIG, 2006: Report on the Research Project OWID - Offshore Wind Design Parameter. - DEWI Magazine 28 (February 2006), 51-53.

NiIno, H., T. Fujitani, N. Watanabe, 1997: A statistical study of tornadoes and waterspouts in Japan from 1961 to 1993. - J. Climate 10, 1730-1752.

Noth, H., 1948: Luftdruckänderung durch Niederschlag (Air pressure changes caused by precipitation). - Meteorol. Rdsch. 1, 210-212. [In German]

REYE, T., 1872: Die Wirbelstürme, Tornados und Wettersäulen in der Erdatmosphäre mit Berücksichtigung der Stürme in der Sonnen-Atmosphäre (The cyclones and tornadoes in the earth's atmosphere, considering also storms in the solar atmosphere). - Carl Rümpler, Hannover, 250 pp., in German, available from essl.org

Simpson, J.S., B.R. Morton, M.C. MCCUMber, R.S. PENC, 1986: Observations and mechanisms of GATE waterspouts. - J. Atmos. Sci. 43, 753-782.
Sioutas, M.V., A.G. KeUL, 2007: Waterspouts of the Adriatic, Ionian and Aegean Sea and their meteorological environment. - Atmos. Res. 83, 542-557.

Stork, C.H. J., C.P. ButTerfield, W. Holley, P.H. MADSEN, P.H. JENSEN, 1998: Wind conditions for wind turbine design proposals for revision of the IEC 1400-1 standard. - J. Wind Engineer. Ind. Aerodyn. 74-76, 443454.

SUCKSTORFF, G.A., 1938: Kaltlufterzeugung durch Niederschlag (Cold air generation by precipitation). - Meteorol. Z. 55, 287-292. [In German]

SugaWARA, Y, F. KobAYASHI, 2008: Structure of a Waterspout Occurred over Tokyo Bay on May 31, 2007. - Sci. Online Lett. Atmos. 4, 1-4, DOI:10.2151/sola.2008-001.

SZILAGYI, W., 2009: A waterspout forecasting technique. - Preprints, 5th European Conf. on Severe Storms, 2 pp., available from www.essl.org/ECSS/2009/preprints/O0514-sziladgyi.pdf

THOM, H.C.S., 1963: Tornado probabilities. - Mon. Wea. Rev. 91, 730-736.

WAKIMOTO, R.M., J.W. WILSON, 1989: Non-supercell tornadoes. - Mon. Wea. Rev. 117, 1113-1140.

Wegener, A., 1917: Wind- und Wasserhosen in Europa (Tornados in Europe). - Verlag Friedrich Vieweg und Sohn, Braunschweig, 301 pp., in German, available at essl.org.

WILD, 1801: Beschreibung einer Wasserhose auf dem Genfer See (Description of a waterspout on Lake Geneva). - Ann. Phys. 7, 70-72. [In German]

WOLKE, C.H., 1802: Nachricht von einer sehr in der Nähe beobachteten Wasserhose (Report of a waterspout observed from close by). - Ann. Phys. 10, 482-487. [In German] 